\title{
Discursive Strategies for the Social Construction in the Post-Conflict Era (2015-2017)*
}

\author{
ANGÉLICA MARÍA RINCÓN RODRÍGUEZ** \\ DORIS LILIA TORRES CRUZ ${ }^{* * *}$
}

Recepción: 27 de abril de 2018

Aprobación: 30 de septiembre de 2018

Forma de citar este artículo: Rincón, A. M. \& Torres, D. L., (2019). Discursive Strategies for the Social Construction in the PostConflict Era (2015-2017). Cuadernos de Lingüística Hispánica, (33), 107-123.

10.19053/0121053X.n33.2019.7978

* $\quad$ Research paper product of a thesis conducted by the PhD. Doris Lilia Torres Cruz, based on the research project titled in Spanish: "Fomento de la Lectura Crítica en la Universidad Pedagógica y Tecnológica de Colombia", identified with the SGI code 2249, from the research group Lenguajes en Educación LEEN (Languages in Education), in the Dirección de Investigaciones of the Universidad Pedagógica y Tecnológica de Colombia, joined with the MA research in Linguistics titled: "Construcción discursiva de los actores sociales del posconflicto en las editoriales del diario El Espectador (2015-2017)", conducted by the student Angélica María Rincón Rodríguez.

** Bachelor in Modern Languages Spanish-English, Master in Linguistic, Research group: Lenguajes en Educación LEEN, Professor of Social Communication program at Universidad de Boyacá. Correo electrónico: angelica.rincon@uptc.edu.co (D) https://orcid. org/0000-0002-1580-4840

*** MA in Linguistics, PhD. in Sciences of Education, Universidad Pedagógica y Tecnológica de Colombia, coordinator of Research Group Lenguajes en Educación LEEN, recognized by Colciencias with the code COL0115263. Correo electrónico: doris.torres@ uptc.edu.co (D) https//orcid.org/0000-0001-7234-3166 


\section{Abstract}

This paper aims to analyze the linguistic and rhetorical resources used in the discursive construction about the social actors of the post-conflict, studying nine editorials of the newspaper El Espectador, between the years 2015-2017. The research is carried out from the perspective of Critical Discourse Analysis (CDA), in order to make a theoretical formulation about journalistic discursive manifestations and a critical reflection on the social realities of journalistic language. The methodology was accomplished in two stages: an exploratory-descriptive and an analytical one. In the first, a compilation of the editorials was made to be submitted to the qualitative analysis program NVivo 11, reporting significant elements such as the frequency of words, co-texts, the Cloudmark and the conglomerates. In the second one a linguistic analysis was implemented to interpret the strategies of legitimation, naturalization and concealment used to construct discursively the social actors of the post-conflict.

Keywords: critical discourse analysis, post-conflict, social actors, language, press, Colombia.

\section{Estrategias discursivas para la construcción social en el posconflicto (2015-2017)}

\section{Resumen}

El objetivo de este artículo de investigación es analizar los recursos lingüísticos y retóricos usados en la construcción discursiva acerca de los actores sociales del posconflicto, mediante el estudio de diez editoriales del diario El Espectador, entre los años 2015 y 2017. La investigación se teje desde la óptica del análisis crítico del discurso (ACD), con el fin de realizar una formulación teórica sobre las manifestaciones discursivas periodísticas y una reflexión crítica sobre las realidades sociales del lenguaje periodístico. La metodología se desarrolló en dos etapas: una exploratoria-descriptiva y otra analítica. En la primera, se hace una recopilación de las editoriales objeto de estudio, para ser sometidas al programa de análisis cualitativo NVivo 11, que da cuenta de elementos significativos como la frecuencia de palabras, los cotextos, la marca de nube y los conglomerados. La segunda implicó la realización de un análisis lingüístico para interpretar las estrategias de legitimación, naturalización y ocultamiento empleadas para construir discursivamente a los actores sociales del posconflicto.

Palabras clave: ACD, discurso, posconflicto, lenguaje, actores sociales, prensa. 


\section{Stratégies discursive pour la Construction Sociale dans l'Ère du Post-Conflit (2015-2017)}

\section{Résumé}

L'objectif de cet article de recherche est celui d'analyser les ressources linguistiques et rhétoriques utilisées dans la construction discursive à propos des acteurs sociaux du post conflit, au moyen de l'étude de dix maisons d'édition du journal El Espectador, de 2015 à 2017. La recherche se tisse à partir d'une optique de l'analyse critique du discours (ACD), afin de réaliser une formulation théorique sur les manifestations discursives journalistiques et une réflexion critique sur les réalités sociales du langage journalistique. La méthodologie a été développée en deux étapes : exploratoire-descriptive et analytique. Dans la première, on fait une compilation des maisons d'édition qui constituaient l'objet d'étude, pour être soumises au programme d'analyse qualitatif NVivo 11. Celui-ci rend compte d'éléments significatifs comme la fréquence de mots, les cotextes, le nuage de mots et les conglomérats. La deuxième a entrainé la réalisation d'une analyse linguistique pour interpréter les stratégies de légitimation, naturalisation et dissimulation employées pour construire discursivement les acteurs sociaux du post conflit.

Mots clés: ACD, discours, post conflit, langage, acteurs sociaux, presse.

\section{Estratégias discursivas para a Construção Social na Era Pós-Conflito (2015-2017)}

\section{Resumo}

0 objetivo deste artigo de pesquisa é analisar os recursos linguísticos e retóricos utilizados na construção discursiva sobre os atores sociais do pós-conflito, através do estudo de dez editoriais do jornal El Espectador, entre os anos de 2015 e 2017. A pesquisa é tecida a partir da perspectiva da análise crítica do discurso (ACD), a fim de fazer uma formulação teórica sobre manifestações discursivas jornalísticas e uma reflexão crítica sobre as realidades sociais da linguagem jornalística. A metodologia foi desenvolvida em duas etapas: uma exploratório-descritiva e uma analítica. Na primeira, faz-se uma compilação das editoras em estudo, para ser submetida ao programa de análise qualitativa NVivo 11, que considera elementos significativos como a frequência das palavras, cotextos, marca da nuvem e conglomerados. A segunda envolveu a realização de uma análise linguística para interpretar as estratégias de legitimação, naturalização e ocultação utilizadas para construir discursivamente os atores sociais do pós-conflito.

Palavras-chave: ACD, discurso, pós-conflito, linguagem, atores sociais, imprensa. 


\section{Introduction}

Nowadays, Colombia faces an unprecedented fact in its history, the end of the conflict with the Revolutionary Armed Forces of Colombia (Fuerzas Armadas Revolucionarias de Colombia, FARC by its acronym in Spanish). This event was a product of a process of negotiations initiated in the city of La Habana (Cuba) in 2012 and concluded with the signature of the "Final Agreement on the Completion of the Conflict and the Construction of a Stable and Lasting Peace" in 2016. The whole process was followed, reported and commented by mass media in the country. Thus, each informative approach has constructed in a discursively way the social actors in the post-conflict era, likewise, allowing the recognition of the victims, the disapproval of the perpetrators and the assignment of responsibilities to the institutions of the State or to the respective government. It is a reason to elucidate the stance of the newspaper El Espectador as one of the largest and most influential diaries of the country.

Taking into account what has being said above, this research assumes the critical discourse analysis (CDA) as the methodology to interpret the discursive strategies used by this newspaper to legitimize or discredit the social actors of the post-conflict. Van Dijk $(1995,1999,2003)$ postulates that critical discourse studies consider language and discourse as the essential elements that allow the understanding of social phenomena. It is from language how subjects can self-construct, perceive themselves as part of a reality and delimit their social space with others. Discourse builds culture and interlaces significances in front of the ways of thinking, perceiving and describing a community. For the discursive analysis of the processes of legitimation, the proposal of linguist Pardo (2007) is taken into account because he clarifies that legitimation occurs when sectors of society, mainly those that represent the forms of power, seek the approval of their actions. It is understood as a way of persuasion and resignification of the ways of seeing the world in order to modify the positions held by the "others" about the phenomena or reality that is being talked about. In the words of political scientist Cruz (2016, p. 132) "legitimation is defined as all those actions tending to justify a relationship of power as suitable, adequate, consistent with the prevailing values, whether this is an existing power relationship or a power relationship potentially generable”. According to Pardo (2007, p. 176), legitimation occurs when rhetorical resources are used, such as authorization, rationalization, evaluation, regulation and mitigation, as euphemisms, hyperboles, metaphors and similes, among others.

Finally, the theory of the social actor Van Leeuwen (1996) is taken as theoretical framework for whom the discursive actor is constructed as an individual or collectivity 
organized and defined by their social, cultural and political practices; representation that is mediated through discourse, as it is stated by Charaudeau (2003, p, 45), "every speaker communicates to modify the state of knowledge, beliefs or the affects of her/his interlocutor, or to make her/him act in a certain way".

From the discourse it is possible to identify the social actors as of inclusion and exclusion mechanisms. In inclusion, the forms of nomination of the actors in the discourse are taken into account; in exclusion, the forms of partial or total elision of the actors in the discourse (Molina, 2009, p. 129).

This research is relevant because it allows understanding how the mass media have discursive power and control over the agenda of the media; it will clarify the way as citizens have access to information about the social realities of the country through them (Tibatá \& Torres, 2018). Thus, the media construction, as a process of positions and interpretation, is made of an incident or event that is mediated by social approach, beliefs and ideological processes of the communicator subject ${ }^{1}$.

\section{Materials and Methods}

This research proposed a mixed approach (quantitative and qualitative), which followed a descriptive analytical process (Wodak, 2003). Quantitative through variables such as frequency of words, thematic associations and concordances. In this phase, a descriptive process was addressed. In the analytical phase, a critical discourse analysis was carried out in which two processes were taken into account, the analysis of the discursive transformation and the analysis of the forms of legitimation. The analysis of the discursive transformation involved the study of the forms of nomination including the recognition of three discursive strategies such as elision, reordering and substitution. Finally, there were analyzed the forms of legitimization, given by such resources as the authorization, the rationalization and the evaluation.

From a universe of more than 30 publishers published in the digital archives, between 2015 and the first quarter of 2017, a total of nine of them were chosen as corpus for the analysis; it is an important period to cover the final stage of the negotiations in La Habana, the signing of a peace agreement and the beginning of its implementation. The selection of criteria focused on making reference to the post-conflict in the context of a

1 An ideology is a complex cognitive framework that controls the formation, transformation and the application of other social cognitions such as knowledge and perceptions, social representations, which include prejudice (Van Dijk, 2009, p. 68). 
socio-cultural situation. Which were subjected to a detailed scanning using the program NVIVO 11 textual statistical software5.

\section{Results and Discussion}

Initially, the research characterized in the newspaper El Espectador a number of most often words in the discourse of the editorials, which were "paz-peace", with $0.85 \%$; "país-country", with $0.45 \%$; "Colombia", with $0.40 \%$; "victimas-victims" and "posconflicto-post-conflict", with $0.39 \%$. Also, it is outstanding the frequency with which the words "Estado-State", with $0.38 \%$ and "Gobierno-Government", with $0.35 \%$ are repeated.

This first approach to the corpus led, as a second process, to identify the co-texts (linguistic units that precede and follow a particular word). The word "post-conflict" was selected (Table 1) as the main unit of analysis with the purpose of understanding the representations and sense assignment that are constructed from the discourse. From the categorization of this process it was identified that $E l$ Espectador symbolically represents the peace process and the signing of the peace agreement in La Habana as "the construction of a coming period that will re-establish order and provide actions to repair the social fabric damaged by violence and armed conflict".

Table 1. Co-Texts of the Word: "Post-conflict"

\begin{tabular}{|l|l|l|}
\hline COTEXTO ANTERIOR & PALABRA & COTEXTO POSTERIOR \\
\hline $\begin{array}{l}\text { Es verdad que ya a esta altura de los } \\
\text { tiempos que comparte la guerrilla de las } \\
\text { Farc y el Gobierno, es hora de ir diseñan- } \\
\text { do una serie de políticas para el }\end{array}$ & Posconflicto & $\begin{array}{l}\text { no solamente como una medida preventiva } \\
\text { frente a la eventual firma de un papel, sino } \\
\text { como un insumo para adelantar los grandes } \\
\text { cambios que Colombia necesita }\end{array}$ \\
\hline $\begin{array}{l}\text { el plan busca garantizar los derechos de } \\
\text { las víctimas, administrar de forma efi- } \\
\text { ciente la justicia, consolidar la seguridad } \\
\text { (ya hemos oído propuestas al respecto), } \\
\text { darle un enfoque territorial al }\end{array}$ & Posconflicto & $\begin{array}{l}\text { modernizar el campo (y vaya si eso sería } \\
\text { importante, teniendo en cuenta el concepto } \\
\text { de modernidad), disminuir las brechas que } \\
\text { tiene con la ciudad, entre otras. }\end{array}$ \\
\hline $\begin{array}{l}\text { Pero sobre todo, el Gobierno debe enten- } \\
\text { der que su paz territorial está en juego y } \\
\text { no depende solamente de firmar con la } \\
\text { guerrilla e implementar unos proyectos } \\
\text { de }\end{array}$ & Posconflicto & $\begin{array}{l}\text { en las regiones. Los jinetes de la muerte si- } \\
\text { guen sueltos y tratarán de impedirlo. }\end{array}$ \\
\hline
\end{tabular}

5 License of Speech Analysis Laboratory of the Master in Linguistcs and the Doctorate in Language and Culture of Universidad Pedagógica y Tecnológica de Colombia. 


\begin{tabular}{|c|c|c|}
\hline COTEXTO ANTERIOR & PALABRA & COTEXTO POSTERIOR \\
\hline La esencia del & Posconflicto & $\begin{array}{l}\text { es la reconciliación, la cual a su vez depende } \\
\text { de que quienes más sufrieron la guerra sien- } \\
\text { tan que se hizo suficiente justicia a través de } \\
\text { la búsqueda de la verdad sobre lo ocurrido y } \\
\text { la reparación de sus daños }\end{array}$ \\
\hline Ahora que se habla de & Posconflicto & $\begin{array}{l}\text { ojalá los procesos de construcción de verdad } \\
\text { arrojen luces, no solamente sobre los atro- } \\
\text { pellos de la guerrilla, sino de los momentos } \\
\text { en que el país les falló a sus ciudadanos. }\end{array}$ \\
\hline Con el & Posconflicto & $\begin{array}{l}\text { viene de la mano una pregunta compleja } \\
\text { sobre cómo aprovechar el desarrollo que } \\
\text { produce la pacificación de las zonas antes } \\
\text { carentes de influencia estatal sin que esto } \\
\text { signifique un desastre en términos de soste- } \\
\text { nibilidad y ambiente }\end{array}$ \\
\hline $\begin{array}{l}\text { Los investigadores advierten que los be- } \\
\text { neficios de los que habla el Gobierno no } \\
\text { se darán solos, pues para que la biodi- } \\
\text { versidad pueda ser un activo social en el }\end{array}$ & Posconflicto & $\begin{array}{l}\text { dependemos, en términos generales, de lo } \\
\text { que nos dejó la guerra y de las políticas y ac- } \\
\text { ciones que sigan. }\end{array}$ \\
\hline $\begin{array}{l}\text { Si permitimos que la columna vertebral } \\
\text { del }\end{array}$ & Posconflicto & $\begin{array}{l}\text { sucumba ante la fuerza de los intereses per- } \\
\text { sonales, no podrá hablarse en Colombia de } \\
\text { verdad, justicia y reparación. }\end{array}$ \\
\hline $\begin{array}{l}\text { Bien por la reestructuración de una Po- } \\
\text { licía para el }\end{array}$ & Posconflicto & $\begin{array}{l}\text { pero mal, muy mal, por el compromiso con } \\
\text { la transparencia. }\end{array}$ \\
\hline $\begin{array}{l}\text { Necesitamos, en efecto, una Policía para } \\
\text { el }\end{array}$ & Posconflicto & $\begin{array}{l}\text { Ojalá esa sea la oportunidad, también, para } \\
\text { cumplir las promesas de transparencia. Así } \\
\text { se construye una mejor convivencia. }\end{array}$ \\
\hline
\end{tabular}

Source: NVivo 11. License of Doctorate Program in Language and Culture - UPTC, Colombia.

This configuration allows it to know a metaphor process of the word "post-conflict"; it highlights specially the structural metaphors, which allow going deep into the mass media concepts about peace post-conflict.

\subsection{Peace is the Way}

A metaphorical concept is evident when it alludes with expressions such as "road map", "lead", "way" to the process that must be taken to reach peace. For this, the term is associated with stages or phases of a journey that must be met to reach the goal. Through the expression "stones in the road" is adduced obstacles in the post-conflict process that must be overcome. Being the National Development Plan the enhancer of that route. The implementation of reforms is invited to alleviate this path; this metaphor, 
therefore, fulfills a didactic function, since it simplifies the way in which the implementation of a peace process is explained to the readers by the newspaper. Example of this the following fragments were taken from the analyzed editorials.

"The road map to trace the road is, of course, the National Development Plan" (Diseñar el posconflicto, 3 de febrero de 2015 -Design the post-conflict, February 3, 2015).

"Reforms necessary to consolidate peace and, likewise, lead the country towards a modernity that has been elusive" (Diseñar el posconflicto, 3 de febrero de 2015- Design the post-conflict, February 3, 2015).

"The details matter a lot when you plan the route of a country" (Diseñar el posconflicto, 3 de febrero de 2015 - Design the post-conflict, February 3, 2015).

"Implementing that territorial peace that has been carefully designed shows us in these final phases that the road is more tortuous than we sometimes believe" (Andan sueltos los jinetes de la muerte, 2 de abril de 2016 -The riders of death are on the loose, April 2, 2016).

\subsection{The Post-Conflict is a Construction}

"[...] and that, the Monday after the voting we can begin to discuss more calmly how we are going to build a new and peaceful country". (Prudencia, por favor, 17 de octubre de 2015 - Prudence, please, October 17, 2015)

"Beyond the number, this force cannot and should not be ignored in the plans to build a new Colombia". (Marchas necesarias, 4 de abril de 2016 - March required, April 4, 2016)

"That said, the issues that the commission did debate are necessary for the construction of a new country". (Las deudas de la policía en el posconflicto, 23 de marzo de 2017 - The debts of the police in the post-conflict, March 23, 2017)

This process of metaphorization shows a series of arguments displayed by the editorialist that tends to explain the benefits of structuring a new country, understanding the expressions "new" and "reinventing" as starting from scratch (Hernández, 2015); Once the peace-process is signed, the post-conflict must be constituted in a construction stage, understanding that it encompasses the area of justice, respect, restitution, reconciliation, truth and protection. This is how it is aimed at institutions, especially the State or Government, to call attention to what is assumed to be responsible for this construction: 
"All of which requires a response from the State that is much more active, strategic and commensurate with the size of the threat" (Andan sueltos los jinetes de la muerte, 2 de abril de 2016 - The riders of death are on the loose, April 2, 2016)

"The State has the enormous challenge of showing that it can protect all political discourses throughout the national territory" (Los están matando, 17 de diciembre de 2016 -They are being killed, December 17, 2016)

Due to the above, it is possible to define that the central theme of $E l$ Espectador discourse refers to the responsibility of the State and Government institutions to provide reparations to the victims and to develop a process of social justice in the country. In this case, by explicitly syndicating the institutions and not the specific social actors, they are hiding and omitting responsibilities, incurring the use of a strategy of partial suppression in discourse mediated by the use of impersonal forms. On the other hand, by defining a thematic nucleus that interweaves with the other propositional references of the discourse, it generates structures of expression that emphasize inclusion and exclusion meanings an evident distinction between "we" and "it":

"That the state that many of us dream of for the so-called post-conflict begins to appear" (Marchas necesarias, 4 de abril de 2016 - March Necessary, April 4, 2016).

"It hurts to have to repeat ourselves: if the bloodshed of the political leaders is not stopped, very difficult times will come for Colombia" (Los están matando, 17 de diciembre de 2016 - They are being killed, December 17, 2016).

"We celebrate that the Government is taking concrete and complex measures to face this problem" (La promesa de la justicia, 17 de marzo de 2017 - The promise of justice, March 17, 2017).

"As it has become habitual with the Government, it is impossible not to agree with the diagnosis, from the discourse, of the problem; but we have to have concrete facts" (Las deudas de la policía en el posconflicto - The debts of the police in the post-conflict).

From the illustrative subject, a position of power and authority is assumed before the judgment of the facts surrounding the political, economic and social situations of the peace and post-conflict process. It offers the reader the parameters on what should be and what should be done in terms of establishing a post-conflict process. The intentionality of the publishers is projected towards the reflection and interpretation of current events that affect a social space. 
The rhetorical question emerges as an argumentative strategy that the newspaper uses to generate some kind of reflection or debate about the events that are being addressed. As a speech act, it fulfills the role of being a way of legitimizing the discourse that covers the level of order, command or advice. In the editorialist discourse, the following functions are highlighted:

- Rhetorical question accompanied, in some cases, by the use of quantifiers to make a call for attention, issuing a warning or inviting action or reflection.

"There are 114 people who were dedicated to the defense of human rights in different regions of the country and who were killed so far this year. What happens, then, impotence state? Is this, perhaps, an insurmountable problem? And, if so, how can we then talk about post-conflict?" (Los están matando, 17 de diciembre de 2016 - They are being killed, December 17, 2016).

- Rhetorical question to be answered, that is, from the same question that emerges a series of arguments is displayed in order to respond to it, becoming a way of self-legitimization when proposing solutions or simply warning about a particular case from its position ideological:

Is it so much vociferation based? (Answer)

"Why, then, that hostile reaction of a portion of the public, of some officials and, we do not avoid the responsibility, of a good part of the media?" (Arguments) (Marchas necesarias, 4 de abril de 2016 - March required, April 4, 2016).

- Rhetorical question for reflection. It is raised in the conclusions of the editorial with the interest that your answer is thought by the reader. In this case, the arguments raised throughout the editorial can influence the way it should be answered.

"And that guarantee (but above all that differential approach) is part of what this country needs for true development. Is it possible?" End of the editorial (Diseñar el posconflicto, 3 de febrero de 2015 - Design the post-conflict, February 3, 2015).

"Will Colombia be able to guarantee that the new missing persons search committee will have all the tools to carry out its work?" (La promesa de la justicia, 17 de marzo de 2017 - The promise of justice, March 17, 2017) 


\subsection{Forms of Nomination and Preaching of the Social Actors of the Post-Conflict}

Broadly speaking, the nomination forms indicate the social actors on which the editorial discourse of $E l$ Espectador revolves and modes of representation. In the first place, the victims are represented by assigning them a role as a patient agent, in which many of the actions of the Government (second discursive actor most named in the editorials) fall and to which an attempt is made to recognize them from the restitution of their rights as a form of construction of a country that is ready to cope with a period like the post-conflict. Second, the State as guarantor and responsible for the restitution of the violated rights of the victims. Third, the armed organizations, as collectivities that restore the social order or contravene the political regime.

In addition, the use of some preaching strategies is reported, in which both positive and negative actions and attributes are imputed to the participants in the post-conflict process. As explained by Prieto (1999), the predicative strategies in the discourse try to attribute both positive and negative actions to the named actors. This strategy seeks the assignment of thematic roles to the actors, also to point out particular characteristics that clarify their role in the discourse "therefore, the use of predicative strategy means for the newspaper $E l$ Espectador a way of interpreting and defining to those who, in one way or another, are the ones in charge or interfere in the construction of post-conflict processes".

In this sense, the use of the predicative strategy for:

a) Highlight actions executed by a social actor. "A group of victims who claim that the State did not do enough to protect them" (Otra condena contra El Estado, 11 de enero de 2017 - Another condemnation against The State, January 11, 2017.

b) Highlight actions that must be fulfilled by other subjects with the main actor "The words of President Juan Manuel Santos are reiterated, reiterating his vehement commitment with the protection and reparation of the victims of the armed conflict in Colombia" (El compromiso con las victimas, 10 de abril de 2016 - The commitment with the victims, April 10, 2016).

It is through this activation or passivation exercise to determine who the power figures in Colombia are, and how El Espectador in its editorials addresses them recognizing 
both their positive and negative role; it is clear that post-conflict policies must be designed by state institutions, implying an active role in decision-making for the creation of a path around reparation. In this case, "we" resort to the activation of actors with institutional affiliation such as: government, state, police, congress. On the contrary, a passive role is assigned to all those actors considered to be violated by the assignments of the conflict; they are described from this editorial discourse in their great majority as agents on which the actions carried out by the branches of public power fall, in addition to actions undertaken by the public force and even executed by illegal forces such as the paramilitary groups, FARC, ELN, among others.

As the common denomination prevails in the discourse, a process of indetermination and impersonalization of the social actors takes place (Figure 2). Highlight, well, the personification strategy; a particular individual is not named, but rather a collective is indicated as the axis of the actions that should or should not be executed in the process of social and identity reconfiguration of the country, establishing the dominant role of some social groups.

"Once the law has been approved, I hope the Government will open the relevant spaces so that the regulations can address the concerns mentioned" Diseñar el posconflicto, 3 de febrero de 2015 - Design the post-conflict, February 3, 2015).

"It is true that already at this point of time that the FARC guerrilla and the Government share, it is time to design a series of policies for the post-conflict" Diseñar el posconflicto, 3 de febrero de 2015 - Design the post-conflict, February 3, 2015).

"This document will be filed at the Congress on February 6, first by the economic commissions, then by the plenary sessions, so as to give a slow discussion" (Diseñar el posconflicto, 3 de febrero de 2015 - Design the post-conflict, February 3, 2015). 
Table 2. Personalization and impersonalization in the discourse

\begin{tabular}{|c|c|c|}
\hline $\begin{array}{c}\text { PROCESO } \\
\text { LINGÜÍSTICO }\end{array}$ & RECURSO & EJEMPLO \\
\hline \multirow[t]{3}{*}{ GENERALIZACIÓN } & Plural sin artículo & $\begin{array}{l}\text { Servidores públicos, líderes de Izquierda, activistas } \\
\text { de tierras, defensores de derechos humanos, cri- } \\
\text { minales, hijos del paramilitarismo, personas, líde- } \\
\text { res sociales, militares, guerrilleros }\end{array}$ \\
\hline & $\begin{array}{l}\text { Singular con artículo defini- } \\
\text { do o indefinido }\end{array}$ & $\begin{array}{l}\text { La población, el uribismo, un grupo poblacional, la } \\
\text { izquierda, los representantes de las instituciones, } \\
\text { un grupo de víctimas, la ciudadanía }\end{array}$ \\
\hline & $\begin{array}{l}\text { Sustantivo de masa sin } \\
\text { artículo }\end{array}$ & $\begin{array}{l}\text { Minoría, partido, personas, movimientos, pobla- } \\
\text { ción, nuevo paramilitarismo }\end{array}$ \\
\hline \multirow[t]{5}{*}{ ESPECIFICACIÓN } & Singular & $\begin{array}{l}\text { El Gobierno, El ELN, la guerrilla, el Ministerio del } \\
\text { Interior, el expresidente, el senador, el fiscal gene- } \\
\text { ral, el Clan Úsuga, el paramilitarismo, la ONU, el } \\
\text { Partido Comunista, la Marcha Patriótica, la Policía } \\
\text { Nacional, la Fuerza Pública, el presidente, la rama } \\
\text { judicial, el Ejército, la Unión Patriótica, el Bloque } \\
\text { Cacique Nutibara }\end{array}$ \\
\hline & Sustantivos de masa & $\begin{array}{l}\text { los sobrevivientes del conflicto, los defensores de } \\
\text { derechos humanos, los líderes políticos, los civiles, } \\
\text { las víctimas, las personas }\end{array}$ \\
\hline & $\begin{array}{l}\text { Sustantivos de colectivo } \\
\text { (nación, comunidad) }\end{array}$ & $\begin{array}{l}\text { La comunidad afro, las comunidades, las autori- } \\
\text { dades, las AUC, los congresistas, la ciudadanía, las } \\
\text { Farc, las bacrim, las comisiones económicas, las } \\
\text { sesiones plenarias. }\end{array}$ \\
\hline & Cuantificadores definidos & Una porción de público, cinco mujeres defensoras. \\
\hline & Cuantificadores indefinidos & $\begin{array}{l}\text { Cualquier criminal, algunos funcionarios, muchas } \\
\text { personas, varios medios, algunos gobiernos, algu- } \\
\text { nos exmilitares. }\end{array}$ \\
\hline
\end{tabular}

Source: own adaptation of Pardo (2007).

Likewise, the discursive strategy of elision is used in many cases to hide an actor, whether this is the cause of an action or plays the role of a subject-patient. In the editorial "Design post-conflict", the suppression process reinforces the strategy of concealment since, its title, the fact of executing an action regarding the creation of post-conflict policies is proposed, but the direct responsibility of who has to execute that action. In addition, the appointment of collectivities is made without making clear an agent that acquires some kind of responsibility. Similarly, it occurs with other owners of editorials, in which actions are announced, but not executors (see Table 3). 
Table 3. Forms of nomination and suppression in the editorials of the newspaper El Espectador

\begin{tabular}{|c|l|l|}
\hline PROCESO LINGÜÍSTICO & \multicolumn{1}{|c|}{ RECURSO EMPLEADO } & \multicolumn{1}{c|}{ EJEMPLO } \\
\hline SUPRESIÓN TOTAL & Frases indeterminadas & $\begin{array}{l}\text { Diseñar el posconflicto. Prudencia, por favor. } \\
\text { El compromiso con las víctimas }\end{array}$ \\
\cline { 2 - 3 } & Eliminación del beneficiario & Los están matando \\
\cline { 2 - 3 } & Mediante adjetivos & $\begin{array}{l}\text { los violentos que solucionan la diferencia } \\
\text { con el miedo y la sangre }\end{array}$ \\
\cline { 2 - 3 } & Estructuras pasivas & $\begin{array}{l}\text { Si no se detiene el desangre de los líderes } \\
\text { políticos, vendrán tiempos muy difíciles para } \\
\text { Colombia }\end{array}$ \\
\hline \multirow{2}{*}{ SUPRESIÓN PARCIAL } & Verbos con función nominal & Marchas necesarias \\
\cline { 2 - 3 } & & $\begin{array}{l}\text { Andan sueltos los jinetes de la muerte. Las } \\
\text { deudas de la policía en el posconflicto. La } \\
\text { promesa de la justicia }\end{array}$ \\
\hline
\end{tabular}

Source: own adaptation of Pardo (2007).

\section{Legitimation Processes in the Editorial Speech of the News- paper El Espectador}

\subsection{Authorization}

Through this strategy, publishers support their argumentation processes in socially accepted sources or experts that validate their positions and arguments against the political scenario of the country with a view to the beginning of the post-conflict. As a discursive strategy legitimizing his speech, the Special Rapporteur uses voices such as: the UN (Organization of the United Nations), the IACHR (Inter-American Court of Human Rights), expert sources, and consolidated report from several sources of information, different studies, among others. Voices that reinforce the resource of authority, relating the post-conflict process as a responsibility of the State with the preservation of human rights; In order for an appropriate post-conflict process to be reached, it is pertinent to review the actions of State institutions and their responsibility in the restitution of rights violated by their institutions and by other legal and illegal armed actors.

"With the look towards there, the war was over, there is the hypothesis of how much the country could grow economically: optimistic calculations place the growth at $4.4 \%$ per year" (Diseñar el posconflicto, 3 de febrero de 2015 - Design the post-conflict, February 3, 2015)

"The UN did not swallow it whole and began to follow up on those murders, not without first warning, in the mouth of its High Commissioner for Human Rights Todd 
Howland, that almost half of these people are related to the Communist Party. Too much coincidence" (Andan sueltos los jinetes de la muerte, 2 de abril de 2016 - The Riders of Death walk, April 2, 2016).

"The IACHR does not consider it that way and, at least in what happened with the Commune 13, its position is more than justified" (Otra condena contra el Estado, 11 de enero de 2017 - Another condemnation against the State, January 11, 2017).

\subsection{Rationalization}

As a legitimation resource, "rationalization occurs when actions are taken as premises from which moral conclusions are drawn about the actors" (Pardo, 2013), is determined:

- The current political discourse generates instability in institutions; it is the politicians who, because of their confrontation or ideological position, represent themselves as selfish beings disinterested in citizen welfare.

- Citizens are those who allow themselves to be dominated and are represented as fearful, obedient and concealing actors of the negative actions of the "others", acting as a consequence of control by armed groups, reinforcing the victim-victimizer relationship.

-Álvaro Uribe, a social actor represented as an opponent of the Government of Juan Manuel Santos, is credited with a moral assessment of his actions in terms of being an unreliable, deceitful and instigating person. This valuation is extended by means of the resource of generalization to the representatives of his party. This assessment establishes him as an enemy of the peace process and consequently of the processes that are carried out for the benefit of the post-conflict.

"The political discourse is reaching a boiling point that should concern any Colombian reasonably interested in the stability of our institutions" (Prudencia, por favor, $17 \mathrm{de}$ octubre de 2015 - Prudence, please, October 17, 2015)

"The true fact is that the fear of the population expressed in their stoic obedience and the discreet reaction of the State despite the announcement in time are proof of the effective power with which these criminals count" (Andan sueltos los jinetes de la muerte, 2 de abril de 2016 - The riders of death walk loose, April 2 of 2016)

"Yes, there are people who have legitimate reasons to doubt characters like Álvaro Uribe and the representatives of his political party. There is still a dangerous mixture be- 
tween justice and politics, trying to sell the idea of a persecution against them" (Marchas necesarias, 4 de abril de 2016 - March required, April 4, 2016).

\subsection{Evaluation}

The evaluation, as explained by Pardo (2013), occurs when the actors are assigned negative or positive point of view, both in the way they are nominated and in the identification of their actions. This strategy of legitimation reinforces the positive self-representation of a "we" and a negative construction of "them". It can be analyzed that:

- Former President Álvaro Uribe is included in the speech, assigning him a negative representation. The lexical expressions "aggressive" and "harmful" used to emphasize in his way of acting against the representatives of the State, builds him as the enemy of institutional stability; his image is discredited by a denial, someone of his "political stature and leadership" should not behave as someone lacking emotional stability.

- The State is constructed in a negative way, incapable of fulfilling its basic responsibilities, citizen security; democratic processes can only be consolidated when the State exercises total control over the territory. The strategy of concealment prevails when a specific actor is not named, sharpening the relationship between the powerful and the dominated.

- With the last two examples, the negative construction of State institutions is reinforced: the Police and the Congress are corrupt. The first, when related to the lack of transparency, is established as a "dark" entity that hides its bad actions. The second, with the term "politiquería-politicking", as the bad way of doing politics that admits power relations constructed from corruption.

The use of the strategy of legitimate evaluation, in most of the times, in a positive way the speech of the newspaper El Espectador, since it shows it close to the citizen, as a mediator who is interested in the welfare of a group. That is why its intention is to denounce debate, announce and syndicate what is being done in an inappropriate way for the interests of the country, reinforcing its positive self-representation (us) from the definition of the others: minorities, politicians, representatives of the State, the police.

"Never before like this week, let's remember there was former President Álvaro Uribe pronouncing such aggressive and damaging accusations against various representatives of the Colombian State that, not long ago, he directed and represented. The anguish and electoral heat, we suppose, have come from any typical decorum of someone of his 
political stature and leadership" (Prudencia, por favor, 17 de octubre de 2017 - Prudencia, please, October 17, 2017).

"The State fails when, in its attempt to regain control, it is unable to give citizens security, nor to create the necessary conditions for democracy to flourish and the construction of communities" (Otra condena contra el Estado, 11 de enero de 2017 - another condemnation against the State, January 11, 2017).

"The obstacles to its approval were a sign of the corrupting power that politicking has" (La promesa de la justicia, 17 de marzo de 2017 - The promise of justice, March 17, 2017).

"Good for the restructuring of a Police for the post-conflict, but bad, very bad, for the commitment to transparency" (Las deudas de la policía en el posconflicto, 23 de marzo de 2017 - The debts of the police in the post-conflict, March 23, 2017).

\subsection{Mitigation}

The mitigation strategy is constructed with the use of euphemisms, lexical processes that aim to minimize or soften the semantic load of the expressions and are very frequent in the journalistic language. In the editorials of the newspaper El Espectador, this rhetorical resource is used to replace words with a negative value and which refer to violent acts committed in the context of conflict and post-conflict. That is, words that fulfill the function of catalyzing the seriousness of the social problems of the country, example of them are the following expressions: territorial control, exercises of authority, false positives, gun plan, peaceful dissent, opposing force, peaceful struggles, differences of vision, submission to justice, natural setbacks, left leaders, acting illicit.

Thus, to refer to acts of violence committed in the armed conflict are used expressions such as gun plan, false positives, exercises of authority and acting illegally. Furthermore, as a linguistic strategy to hold these acts accountable without making explicit that the punishment must be jail, the linguistic unit subjected to justice is used. To refer to the different points of view that converge in the post-conflict scenario, terms such as peaceful dissent, peaceful struggles, differences of vision and natural setbacks are used expressions that allow a rapprochement and lighten the discourse to include left leaders and social groups as social groups, opposing forces.

"Without entering into political recognition, there are decent legal opportunities for women to find attractive a submission to justice, without disparagement to the vic- 
tims” (Andan sueltos los jinetes de la muerte, 2 de abril de 2017 - The riders of death walk loose, April 2, 2017).

\subsection{Warning}

As a discursive strategy of argumentation, the warning presents the recipients with a set of reasons and arguments that, oriented to their feelings and sensitivity, warn of the consequences and the implications that certain behaviors and actions can cause (Serrano \& Villalobos, 2008).

"[...] that if they do not take seriously the retaining walls that remain firm against peace, this unique opportunity for Colombia can be diluted in the persistence of violence" (Andan sueltos los jinetes de la muerte, 2 de abril de 2016 - The Riders of Death walk loose, April 2, 2016).

"You cannot allow the answer to be hate. Colombia already knows with sufficient illustration what causes the polarization" (Marchas necesarias, 4 de abril de 2017 - March necessary, April 4, 2017).

- In the first example, the warning strategy is used to specify that there are groups that oppose the peace process, which it metaphorizes with the expression "retaining walls", which is why they are characterized as an obstacle in the way to which they should be paid attention, since it is they who, through the use of violence, could make the much longed for peace fail.

- With the second example, the voice of command attributed to the newspaper by using the expression "cannot afford" is used to warn that polarization or opposing positions regarding the peace process generate hate actions that bring negative consequences. In this example, intertextuality is incurred to appeal to something that is already known and it is not necessary to name it again "Colombia already knows with enough illustration". The word Colombia is metaphorized as a mechanism of inclusion in the discourse.

\section{Conclusions}

Bearing in mind that the purpose of this research was to analyze the discursive strategies and rhetorical resources used by the newspaper El Espectador to discursively construct the post-conflict and its discursive actors, its staging allowed to reveal in the nine editorials analyzed, the position that as a means of communication assumes against this phenomenon. In this sense, it is possible to conclude that the use of these resources facilitated forms of legitimation and delegitimization of social actors through mechanisms of inclusion, exclusion, concealment and naturalization. It is understood that its role as 
mass media is based on persuasion as a mode of argumentation that seeks adherence to its points of view (Calsamiglia \& Tusón, 2002).

In the first place, it conceptualized the post-conflict as a construction process, in which it mediates the actions of the State and the Government to achieve it. This position allowed us to highlight the discursive actors that, in one way or another, are of vital importance to bring this process to a successful conclusion. It resorts to the use of metaphorical forms, attribution of characteristics, forms of nomination, activation and passivation as strategies that propitiate mental models, which produce in the possible speakers of the discourse at the cognitive level the establishment of representations about the facts and people that are spoken about.

\section{References}

Calsamiglia, H. \& Tusón, A. (2002). Las cosas del decir. Manual de análisis del discurso. Barcelona: Ariel.

Charaudeau, P. (2003). El discurso de la información. La construcción del espejo social. Barcelona: Gedisa.

Cruz, C.N. (2016). El enfoque de legitimación y dinámica política (LDP) como propuesta para el estudio de la estabilidad y el cambio de las políticas públicas. (Tesis doctoral). Universidad Complutense de Madrid, España.

Hernández, N. (2015). La construcción mediática de perdedores y vencedores en el campo político: análisis de las metáforas, tópicos y lexicalización. Cuadernos de Lingüística Hispánica, (25), 81-98. doi: http://dx.doi.org/10.19053/ 0121053X.3479

Molina, J. (2009). La representación social del fenómeno del desplazamiento forzado en la prensa colombiana. Universitas Humanística, 67, 127-146.

Pardo, N. G (2007). Cómo hacer análisis crítico del discurso. Una perspectiva latinoamericana. Recuperado de: http://www.bdigital.unal.edu.co/10250/1/C\%C3\%B3mo $\% 20$ hacer $\% 20$ ACD.pdf

Prieto, C. D. (1999). El juego del discurso. Manual de análisis de estrategias discursivas. Buenos Aires: Lumen Hvmanitas.

Serrano, S. \& Villalobos, J. (2008). Las estrategias argumentativas en textos escritos por estudiantes de formación docente. Letras, 77(50), 76-102. 
Tibatá H. \& Torres, D. (2018). Communicative Interaction for the Construction of the Wasteland in Postconflict's Colombia. Asian Journal of Humanities and Social Studies, 6(2), 6072. https://doi.org/10.24203/ajhss.v6i2.5271

Van Leeuwen, T (1996). The representation of social actors in discourse. In C. R. Coldas-Coulthard \& M. Coulthard, (ed.), Texts and practices: Readings in critical discourse analysis (pp.32-70). London: Routledge.

Van Dijk, T. A. (1995). Discourse Analysis as Ideology Analysis. In C. Schäffner \& A. Wenden (ed.), Language and Peace (pp. 17-36). Amsterdam: Harwood Academic Publishers.

Van Dijk, T. A (1999). El análisis crítico del discurso. Barcelona: Anthropos.

Van Dijk, T. A. (2003). Ideología y discurso. Una introducción multidisciplinaria. Barcelona: Ariel.

Van Dijk, T. A. (2009). Discurso y poder. Barcelona: Gedisa.

Wodak, R. \& Meyer, M. (2003). Métodos del análisis crítico del discurso. Barcelona: Gedisa. 